\title{
Membedah Al-KashshāF; Karya Muktazilah Yang Menjadi Rujukan Ahlussunah Wal Jamaah
}

\section{Abdul Syukkur \\ Sekolah Tinggi Ilmu Ushuluddin (STIU) Al-Mujtama Pamekasan Abdulsyukkur83@gmail.com}

\begin{abstract}
The difference in opinion between Ahlus sunnah wal jamaah and Muktazilah has reached the point of misleading one another. Thus, reference sources for one sect will not be used as a reference for other sects, but this is not the case with al-Kashshäf which is the work of Muktazilah which is the reference for the ulamaAhlussunnah wal Jamaah. This article examines the book al-Kashshäf by al-Zamakhshari al-Mu'tazili, its writing background, the biography of the author, the characteristics of the book al-Kashshaf, its advantages and disadvantages, the interpretation which is the point of criticism of Ahlussunnah wal Jamaah, and Appreciation of Ulama Ahlussunnah wal Jamaah for al-Kashshāf.
\end{abstract}

Keywords: Al-Kashshāf, al-Zamakhsharī, Muktazilah, Ahlussunnah wal Jamaah.

Abstrak: Perbedaab pendapat antara Ahlus sunnah wal jamaah dengan Muktazilah sampai pada titik saling menyesatkan antara yang satu dengan yang lain. Sehingga, sumber-sumber rujukan aliran yang satu tidak akan dijadikan rujukan bagi aliran yang lain, tapi tidak demikian dengan al-Kashshäf yang merupakan karya Muktazilah yang menjadi rujukan ulama-ulama Ahlussunnah wal Jamaah. Artikel ini membedah kitab al-Kashshäf karya al-Zamakhshari al-Mu'tazili, latar belakang penulisannya, biografi penulisnya, karakteristik kitab al-Kashshäf , kelebihan dan kekurangannya, interpretasi yang menjadi titik kritik Ahlussunnah wal Jamaah, dan apresiasi ulama Ahlussunnah wal Jamaah terhadap al-Kashshäf.

Kata Kunci: Al-Kashshāf, al-Zamakhsharīi, Muktazilah, Ahlussunnah wal Jamaah.

\section{Prolog}

Setiap karya memiliki keistimewaan tersendiri, yang mana keistimewaan tersebut tidak lepas dari siapa yang menghasilkan

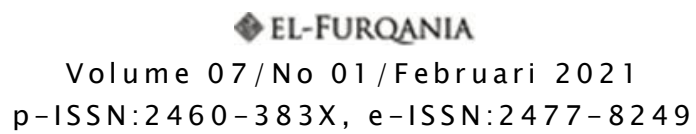


karya, perjalanan hidup dia dalam dunia keilmuan, bagaimana dampak karya tersebut dalam kehidupan, dan bagaimana tanggapan para ilmuan lain terhadap karya tersebut.

Al-Kashshāf merupakan salah satu karya yang jika dilihat dari segi siapa pengarangnya tidak diragukan lagi, dialah yang mendapat julukan järullah, kemampuannya dalam dunia keilmuan, terutama yang berkaitan dengan tata bahasa Arab beliau sangat mumpuni. Hal ini mendapat pengakuan dari adh-Dhahabi: setiap kali Zamakhshari memasuki sebuah wilayah penduduk wilayah tersebut berbondongbondong belajar kepada beliau, dan setiap kali beliau berdebat dengan seseorang, orang yang diajak berdebat tersebut selalu kalah dan mengakui keilmuannya, sehingga beliau menjadi sangat terkenal, dan menjadi salah satu ulama terpandang pada masanya. ${ }^{1}$

Sementara dilihat dari segi karya dan pendapat ulama mengenai karya tersebut, banyak yang mengakui bahwa al-Kashshāf merupakan kitab yang mendapatkan pengakuan dari kawan (Muktazilah) maupun lawan (Sunni) dan mendapatkan ketenaran yang sangat luas, sehingga membuat beberapa ulama tertarik untuk menulis tentang kitab ini, sungguh hal ini merupakan bukti nyata bahwa al-Kashshāf merupakan kitab tafsir yang sangat berharga. ${ }^{2}$

Dalam makalah ini, pemakalah membahas mengenai beberapa hal tentang Zamakhshari sendiri sebagai pengarang dan tentang alKashshāf sebagai karya yang sering dijadikan rujukan oleh para ulama, yang meliputi kajian mengenai metodologi al-Kashshāf sendiri.

\section{Biografi Al-Zamakhshari}

Kitab ini merupakan kita yang dikarang oleh Abū al-Qāsim Jārullah Mahmūd bin Umar bin Muhammad bin Ahmad bin Umar alZamakhshari al-Khawarizmi, beliau lebih dikenal dengan nama alZamakhshari, lahir di Zamakhshar pada hari Rabu 27 Rajab $467 \mathrm{H}$. atau 18 Maret $1075 \mathrm{M}$ dan meninggal dunia pada tahun $538 \mathrm{H}$. Zamakhshar adalah suatu desa di Khawarizm, terletak di wilayah

\footnotetext{
${ }^{1}$ Muhammad Husain adh-Dhahabì, al-Tafsìr wa al-Mufassirūn, (Kairo: Dār alHadith, 2005), Juz 1, 362.

${ }^{2}$ Ibid. hlm. 372.
} 
Membedah Al-KashshāF; Karya Muktazilah Yang Menjadi Rujukan Ahlussunah Wal Jamaah

Turkistan, Rusia, yang sekarang masuk dalam negara Uzbekistan bagian dari Uni Soviet.

Sejak kecil beliau hidup acuh tak acuh, sering berbuat ulah dan sering dimarahi ibunya, sehingga pengaruh ibunya lebih besar daripada pengaruh ayahnya bagi Zamakhshari kecil. Pernah suatu hari ada seekor burung pipit yang hinggap di samping Zamakhshari, ia menangkap burung itu, lalu mengikat kakinya dengan benang, kemudian setelah itu menarik dan menyeret burung tersebut hingga kakinya putus dan burung itu terbang dengan benang yang masih melelet di sisa kakinya yang sebagian telah putus. Kejadian tersebut diketahui ibunya sehingga sang ibu marah-marah dan sampai terlontar kata-kata, "Semoga kakimu put us sebagaimana kaki burung pipit itu". ${ }^{4}$

Takdir berjalan sesuai dengan doa ibunya, dalam perjalanan hidupnya, Zamakhshari dibenturkan dengan kebutuhan hidup yang mengharuskan beliau menempuh perjalanan ke daerah Khawarizm, sebuah tempat yang sangat dingin, sehingga membuat kakinya mengalami lumpuh, dan puncaknya pada suatu hari ketika beliau sedang mencari ilmu di Bukhārā, beliau terjatuh dari kendaraannya, sehingga kakinya yang sudah lumpuh menjadi putus dan terpisah dari tubuhnya. Semenjak saat itu, beliau berkelana mencari ilmu dengan menggunakan tongkat penyangga kakinya yang tinggal sebelah, akhirnya beliau menetap di dekat Masjidil Haram di Mekah, sehingga beliau mendapat julukan järullah (tetangga Allah), karena tempat tinggal beliau yang berada di dekat masjidil haram ${ }^{5}$.

Perjalanannya dalam mencari ilmu dimulai sejak usia remaja, Zamakhshari merantau untuk menuntut ilmu pengetahuan ke Bukhārā, yang pada saat itu menjadi pusat keilmuan, namun tak lama dari itu, beliau kembali ke Khawarizm dan menuntut ilmu kepada ulama terkenal, yaitu Abū Mudar al-Nahwì (w. 508 H.) pada ulama ini, beliau belajar bahasa dan sastra Arab, logika, filsafat dan ilmu kalam. Selanjutnya, Zamakhshari melanjutkan perjalannnya ke Baghdad, di kota ini beliau mengikuti pengajian hadisnya Abū al-

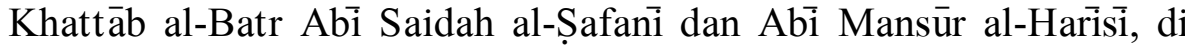

\footnotetext{
${ }^{3}$ Mannā' Kha「il al-Qatțān, Studi Ilmu-ilmu al-Qur'an, terj. Mudzakir AS. (Jakarta: Litera Antarnusa, 2001), 530.

${ }^{4}$ Yusuf al-Hammadi dalam pengantar editor al-Kashshāf karya Zamakhsharī, (Kairo: Maktabah Misr, t.th.), Hal 3.

${ }^{5}$ Ibid. 3
} 
samping itu, beliau juga mengikuti pengajian fikihnya ahli fikih Hanafi, yaitu al-Damagani al-Sharif bin as-Shajari. ${ }^{6}$

Setelah beberapa tahun menggeluti ilmu pengetahuan agama, Zamakhshari sempat bergelut di bidang pemerintahan dan sampai menjadi kātib (sekretaris), hanya saja beliau tidak puas dengan jabatan dan situasi pemerintahan ketika itu, sehingga beliau memutuskan untuk berkonsentrasi lagi dalam bidang ilmu-ilmu agama. $^{?}$

\section{Karya-karya Zamakhshari}

Dari segi keilmuan, Zamakhshari sudah tidak diragukan lagi, terutama dalam bidang ilmu bahasa, ma'anī, bayān, hadith, fikih, tafsir dan lain sebagainya. Selain kitab al-Kashshāf yang sangat fenomenal tersebut, beliau juga memiliki beberapa karya dalam bidang-bidang yang lain, diantaranya: al-Fà'iq fí Tafsir al-Hadith, Mutashābih Usāmi al-Ruwät, Rabì' al-Abrär, Nusūus al-Akhbār, alNașāih al-Kibār, Nașāih al-Ṣighār, ar-Rā'id fï al-Farāid, Dīwān Rasā'il, Dīwān al-Tamāsil, Dīìān ash-Shi'ri, al-Qiștạs, al-Budūr asSāfirah fì al-Amthāl as-Säirah, Tāliyāt al-Ḍarīr, Asās al-Balāghah, Jawāhir al-Lughah, al-Ajnas, Muqadimah al-Adab, an-Namūzaj fí alNahwi, Sharh al-Kitab Sibawaih, Sharh al-Mufasșal fï al-Nahwi, Mu'jam al-Hudūd, al-Minhāj fỉ al-Ușūl, Shaqāiq al-Nu'mān fì Haqāiq al-Nu'mān, Shāfi al- 'Ayyi min Kalām al-Shäfi' 'ì.

\section{Latar Belakang Penulisan Kitab Tafsir Al-Kashshāf}

Judul kitab tafsir ini adalah al-Kashshäf 'an Haqāiq al-Tanzīl wa 'Uyūn al-Aqāwìl fī Wujūh al-Ta'wìl. Menurut pengakuan Zamakhshari, latar belakang ditulisnya karya ini berawal dari permintaan sebagian sahabat sekaligus murid-murid beliau yang ketika meminta dijelaskan tentang tafsir suatu ayat kepada beliau, beliau menjelaskannya dengan gamblang, seakan terbuka tabir yang selama ini menutupi mereka, dan mereka pun kagum dengan kemampuan Zamakhshari dalam menafsiri ayat-ayat al-Qur'an. Dari sinilah mereka yang menamakan diri sebagai al-fiah al-nājiyah wa al'adliyah yaitu, sahabat-sahabat beliau yang memiliki faham yang sama dengan Zamakhshari meminta beliau untuk menulis karya tafsir

${ }^{6}$ Zamakhshari, al-Kashshāf, (Kairo, Maktabah Misr, t.th.), Juz 1, Hal. 9.

${ }^{7}$ Ibid. Juz 4, hlm. 659

8 Ibid. 659. 
sebagaimana beliau menafsirkan ayat-ayat al-Qur'an kepada sahabatsahabat beliau?.

\section{Keistimewaan dan Kekurangan Tafsīr al-Kashshäf}

Tafsir al-Kashshaf yang penulis kaji dicetak oleh Maktabah Misr, diedit oleh Yusuf al-Hammadi, cetakan ini terdiri dari 4 jilid, jilid pertama berisi pengantar penerbit, pengantar editor dan pengantar penulis sendiri yang beliau sebut dengan khutbah al-kitāb, dalam pengantarnya, penulis kitab menjelaskan tentang kemukjizatan al-Qur'an, ketinggian balaghahnya, pentingnya menguasai ilmu-ilmu tentang al-Qur'an dibanding dengan ilmu-ilmu yang lain, latar belakang penulisan tafsir ini, di mana ditulis dan memakan waktu berapa lama ${ }^{10}$.

Jilid pertama juga memuat tafsir Surat al-Fātihah sampai ayat ke 171-176 dari surah al-Nisā (surah kelima), jilid kedua berisi penafsiran ayat pertama dari Surat al-Māidah sampai pada Surat alNahl ayat ke 105-128, jilid ketiga berisi penafsiran mulai ayat pertama Surat al-Isrā' sampai Surat al-Saffăt ayat 114-182, dan jilid keempat berisi penafsiran ayat pertama Surat Sād sampai ayat ke 6 Surat al-Nās. Pada jilid 4 pula ditambah dengan beberapa keterangan tentang Zamakhshari, seperti biografinya, tempat dan tanggal lahirnya, karya-karyanya, julukan dan sebab putusnya kakinya, ijazah-ijazah karya-karyanya, dan tanggal serta tempat wafatnya. Di bagian akhir jilid 4 tertera daftar isi kitab secara keseluruhan, mulai dari jilid 1 sampai jilid 4.

Tafsir al-Kashshāf yang penulis kaji merupakan terbitan Maktabah Mișr Mesir tanpa tahun terbit.

Kitab al-Kashshāf memiliki beberapa keistimewaan di antaranya adalah: bahasanya singkat dan tidak bertele-tele, seperti ketika beliau menafsirkan ayat:

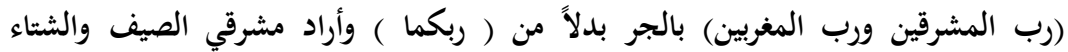

"Tuhan yang memelihara kedua tempat terbit matahari dan Tuhan yang memelihara kedua tempat terbenamnya". ${ }^{11}$

\footnotetext{
${ }^{9}$ Zamakhshari, al-Kashshāf, (Kairo, Maktabah Misr, t.th.), Juz 1, Hal. 9.

${ }^{10}$ Ibid. 10.

${ }^{11}$ Departemen Agama, al-Qur'an dan Terjemahnya, (Jakarta: J-Art, 2000), 533.
} 
Zamakhshari menafsirkan kalimat ini dibaca jar sebagai badal dari rabbikuma dan maksudnya adalah tempat terbit dan terbenamnya matahari di waktu musim panas dan musim dingin. ${ }^{12}$

Dalam menafsirkan, Zamakhshari sering menggunakan metode dialog dengan mengatakan, jika kamu mengatakan (inqulta) seperti ini atau bertanya, maka Zamakhshari mengatakan (qultu) saya menjawab, sebagaimana dalam menafsirkan ayat 46 dalam surat alRahmān:

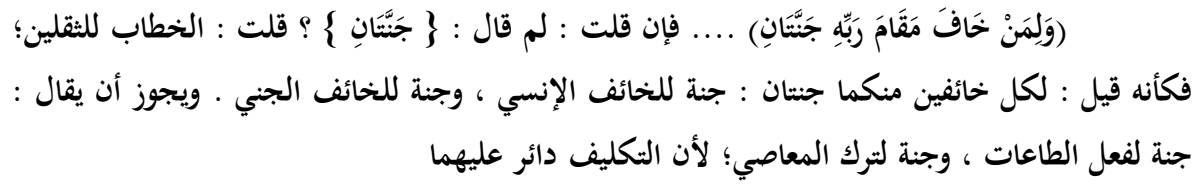

Dan bagi orang yang takut akan saat menghadap Tuhannya ada dua sorga. ${ }^{13}$

Zamakhshari kemudian menyebutkan, jika kamu bertanya: mengapa Allah berfirman ada dua sorga? Maka saya (Zamakhshari) menjawab: khițāb (objek bicaranya) untuk manusia dan jin, Allah seakan berfirman: bagi mereka yang takut dari masing-masing jenis kalian berdua ada dua sorga, satu sorga untuk mereka yang takut dari golongan manusia dan satu sorga bagi mereka yang takut dari golongan jin.

Bisa juga dikatakan: satu sorga untuk perbuatan taat dan satu lagi diberikan karena meninggalkan larangan, karena perintah dari Allah terdapat dalam keduanya. ${ }^{14}$

Keistimewaan lain dari kitab tafsir ini adalah lebih menekankan unsur kebahasaan, dengan menjelaskan arti bahasa menggunakan syair Arab, dan juga banyak menekankan aspek kemukjizatan al-Qur'an dari segi balaghiyah-nya, hal ini menjadi ciri khas tafsir al-Zamakhshari, sehingga tidak heran jika hampir semua ayat, dan bahkan kata dalam setiap ayat dibahas masalah kebahasaannya, sebagaimana dalam menafsirkan ayat pertama dalam Surat al-Wāqi'ah:

\footnotetext{
${ }^{12}$ Zamakhshari, al-Kashshāf, (Kairo, Maktabah Misr, t.th.), Juz 4, Hal. 320.

${ }^{13}$ Departemen Agama, al-Qur'an dan Terjemahnya, (Surabaya, UD. Mekar, 2000), 534.

${ }^{14}$ Zamakhshari, al-Kashshāf, (Kairo, Maktabah Misr, t.th.), Juz 4, Hal. 324.
} 


$$
\begin{aligned}
& \text { (إِذَا وَقَعَتِ الْوَاقِعَة) كقولك : كانت الكائنة ، وحدثت الحادثة ، والمراد القيامة : وصفت }
\end{aligned}
$$

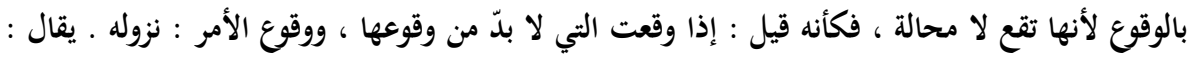

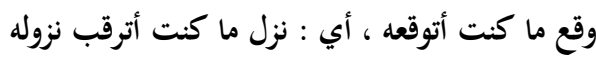

"Apabila terjadi hari kiamat"15. Seperti perkataanmu: kejadian itu benar-benar terjadi atau peristiwa itu benar-benar terjadi, yang dimaksud adalah hari kiamat. Disebut kejadian (peristiwa) karena hal itu akan benar-benar terjadi, sebagaimana ada orang yang mengatakan: jika terjadi kejadian yang benar-benar harus terjadi, terjadinya suatu perkara adalah terlaksananya, dikatakan: telah terjadi apa yang saya duga, yakni telah terjadi peristiwa yang aku tunggu-tunggu. ${ }^{16}$

Zamakhshari juga menyebutkan beberapa versi bacaan dalam satu ayat, misalkan ketika beliau menafsiri ayat 31 dari Surat alBaqarah:

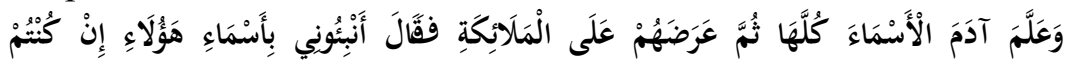

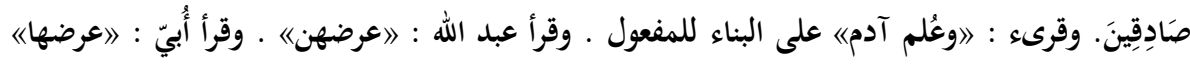

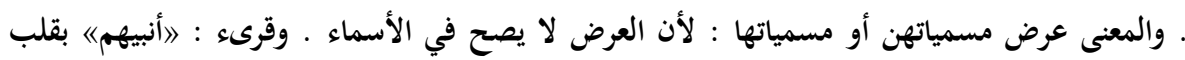

$$
\begin{aligned}
& \text { الهمزة ياء ـ 》وأنبهم/ بحذفها والهاء مكسورة فيهما }
\end{aligned}
$$

Setelah menafsiri ayat di atas, beliau kemudian menyebutkan versi lain bacaan ayat tersebut, seperti kata 'allama yang dibaca 'ullima, dan bacaan versi Abdullah bin Mas'ud yang membaca 'aradahum dengan 'aradahunna dan Ubai bin Ka'b yang membacanya dengan 'aradahă. Sedangkan kata ambi'hum dibaca ambi him dengan mengganti huruf hamzah menjadi ya' dan juga dibaca ambihim dengan membuang huruf $y a^{, 17}$

Pada setiap kali mengakhiri penafsiran suatu surat, Zamakhshari selalu menyebutkan riwayat yang menjelaskan keutamaan surat tersebut, seperti ketika beliau menafsiri surat alBaqarah, pada akhir penafsiran surat tersebut beliau menyebut riwayat yang berbunyi:

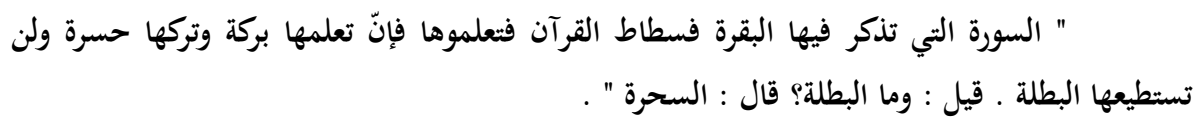

${ }^{15}$ Departemen Agama, al-Qur'an dan Terjemahnya, (Surabaya: UD. Mekar, 2000), 535 .

${ }^{16}$ Zamakhsharī, al-Kashshāf, (Kairo, Maktabah Misr, t.th.), Juz 4, Hal. 327.

${ }^{17}$ Ibid. 119. 
"Surat yang di dalamnya disebutkan kisah mengenai sapi betina merupakan yup-yupanya al-Qur'an, maka pelajarilah, karena mempelajarinya merupakan berkah, sedangkan meninggalkannya merupakan kerugian, dan bagi yang membacanya tidak akan terkena batalah, sahabat bertanya: apa itu batalah? Nabi menjawab: sihir" ${ }^{\prime 18}$

Penulis kesulitan mengategorikan penyebutan riwayat seperti ini, apakah termasuk keistimewaan atau justeru kekurangan. Jika ditilik dari segi bertambah lengkapnya penafsiran suatu ayat dalam satu surat, penambahan riwayat seperti ini menjadi keistimewaan, tapi jika ditilik dari segi validitasnya, maka penambahan riwayat seperti ini akan menjadi kekurangan, karena Zamakhshari hanya menyebutkan riwayat tersebut dengan mengatakan: dari Rasulullah Saw. kemudian menyebutkan riwayatnya, tanpa menyebut siapa perawi yang mengeluarkan riwayat tersebut dan siapa nama sahabat Nabi yang meriwayatkannya dari Nabi saw., hal ini menyulikan pembaca untuk menilai kebenaran riwayat tersebut.

Sementara yang menjadi kelemahan dari tafsir al-Kashshāf menurut penulis adalah penyebutan riwayat-riwayat Israiliyāt yang sering beliau sisipkan dalam penafsiran beberapa ayat, seperti ketika beliau menafsirkan ayat:

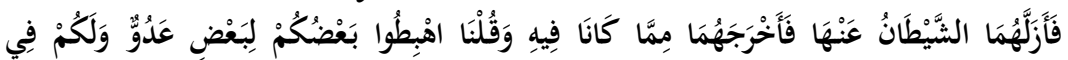

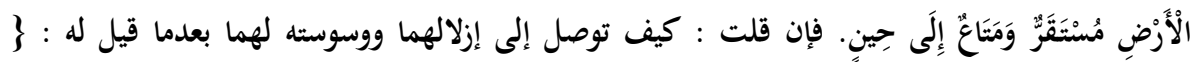

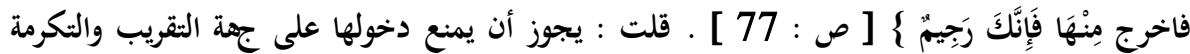

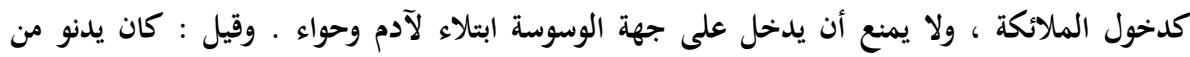

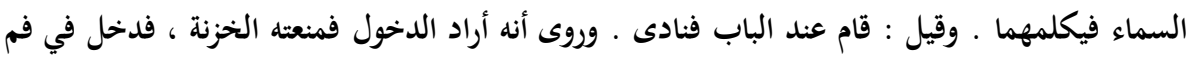
الحية حتى دخلت به وهم لا يشعرون

Ketika menafsirkan ayat di atas, Zamakhshari menyebutkan beberapa riwayat yang di antara riwayat tersebut terdapat riwayat Israiliyyāt tanpa menyebutkan siapa sumber riwayat tersebut. Riwayat Israiliyyāt yang penulis maksud dalam kutipan tafsir alKashshāf di atas adalah pernyataan Zamakhshari yang menyebutkan: diriwayatkan bahwa Iblis ingin masuk ke dalam sorga tapi dilarang oleh malaikat penjaga sorga, kemudian Iblis masuk ke dalam mulut ular, sehingga dia masuk dan mereka tidak ada yang mengetahui hal itu. $^{19}$

18 Ibid. 295.

${ }^{19}$ Ibid. 121. 
Ada pula kekurangan yang menurut sebagian ulama, seandainya tanpa kekurangan ini semestinya kitab al-Kashshāf menjadi kitab yang layak menjadi pegangan setiap muslim, yaitu Zamakshari sering memaksakan penafsiran suatu ayat sesuai dengan faham Muktazilah, hal ini diakui pula oleh Ibnu Khaldun dalam muqaddimahnya, "Kekurangan tafsir al-Kashshaf adalah sering membela faham muktazilahnya dalam menafsiri al-Qur' an". ${ }^{20}$

Pemaksaan penafsiran ayat yang harus sesuai dengan faham Muktazilah nampak jelas ketika Zamakhshari menafsiri ayat 16 dari Surat al-Qiyāmah:

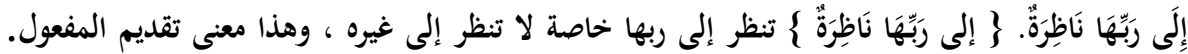

$$
\begin{aligned}
& \text { فإنّ المؤمنين نظارة ذلك اليوم لأنهم الآمنون الذين لا خوه كُف عليهم ولا هم يحزنون ، فاختصاصه بنظرهم }
\end{aligned}
$$

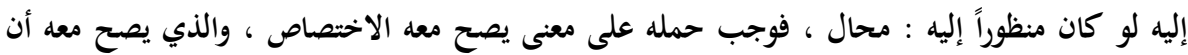

$$
\begin{aligned}
& \text { يكون من قول الناس : أنا إلى فلان ناظر ما يصنع بي ، تريد معنى التوقع والرجاء. }
\end{aligned}
$$

Zamakhshari mengartikan kata näzirah di atas dengan mengharap rahmat dan pahala dari Allah dan tidak mengartikannya dengan melihat, karena jika diartikan melihat akan bertentangan dengan pendapat Muktazilah bahwa Allah tidak bisa dilihat meski di akhirat nanti.

Hal ini dianggap kelemahan karena bertentangan dengan hadith yang diriwayatkan oleh al-Bukhari dalam kitab shahihnya: ${ }^{21}$

حدثنا عمرو بن عون حدثنا خالد أو هشيم عن إسماعيل عن قيس عن جرير قال : كنا جلوسا عند النبي

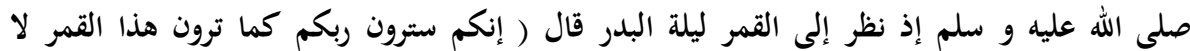

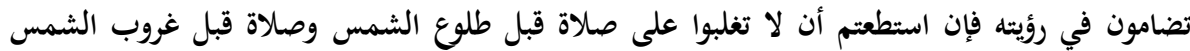

Hadis ini menjelaskan sabda Nabi bahwa manusia akan melihat Allah sebagaimana melihat rembulan. Berpijak pada sumber ini kemudian ahlu al-sunnah yang menyebutkan bahwa Allah bisa dilihat di akhirat nanti, sebagaimana penafsiran-penafsiran para ulama tafsir ahlus sunnah seperti, Ibnu Kathï dan Ibnu Jarir alTabari, misalkan kita lihat penafsiran Ibnu Kathïr pada ayat yang sama:

\footnotetext{
${ }^{20}$ Ibnu Khaldūn, Muqaddimah Ibnu Khaldūn, (Kairo: Maktabah at-Taufikiyah, t.th.), Hal. 489.

${ }^{21}$ Muhammad bin Isma'il Al-Bukhārī,, Shahīh al-Bukhāri, (Bairūt, Dār Ibnu Kathīr, 1987 M), juz 1, 203.
} 


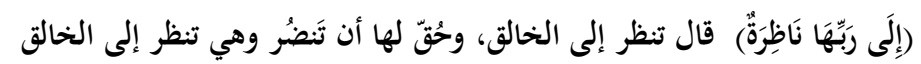

Akan melihat kepada Sang Pencipta. ${ }^{22}$

Ibnu Jarir al-Tabari juga menafsirkan dengan penafsiran yang sama, yaitu bahwa Allah bisa dilihat di akhirat nanti:

$$
\begin{aligned}
& \text { ( إلَّى رَبِّهَا نَاظِرَة ) قال: أخبرني يزيد النحوي، عن عكرِمة وإسماعيل بن أبي خالد، وأنياخ من أهل } \\
& \text { الكوفة، قال: تنظر إلى ربها نظرا. }
\end{aligned}
$$

Setelah menyebutkan pendapat beberapa ulama, kemudian alTabari menyatakan bahwa para penduduk sorga akan melihat Allah di akhirat nanti. $^{23}$

Pernyataan al-Ṭabari mengenai kemungkinan Allah bisa dilihat di akhirat nanti dikuatkan lagi dalam menafsiri ayat:

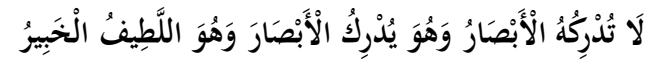

al-Ṭabari lalu menyinggung ayat yang menyebutkan kemungkinan penduduk sorga bisa melihat Allah di akhirat:

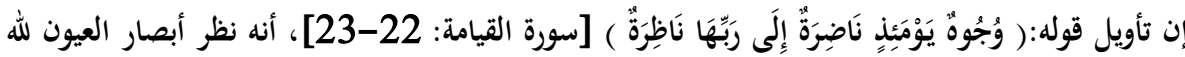

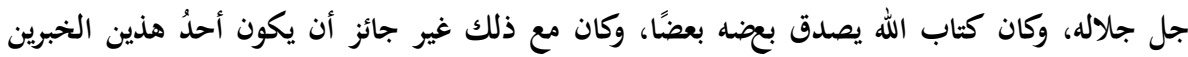

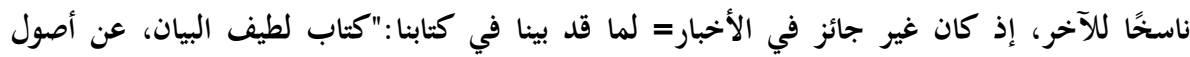

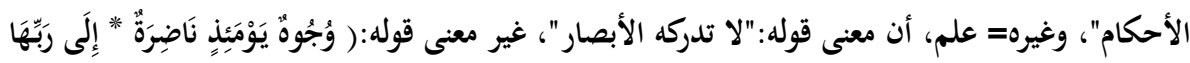

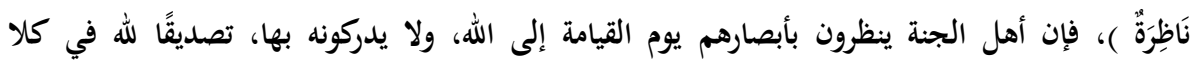

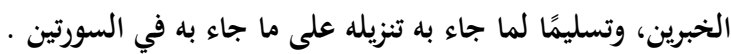

Penafsiran al-Tabari di atas menguatkan pendapatnya bahwa Allah bisa dilihat dengan penglihatan mata, karena menurut beliau, antara pernyataan al-Qur' an bahwa Allah bisa dilihat tidak bertentangan dengan hadith Nabi yang diriwayatkan al-Bukhäri ${ }^{24}$,

\footnotetext{
${ }^{22}$ Ibnu Kathīr, Tafsìr al-Qur'ān al-'Adhïm, (t.t. Dār Ṭayyibah, 1999), 578.

${ }^{23}$ Al-Tabarì, Jāmi' al-Bayān fì Ta'wìl al-Qur'ān, (Bairūt, Muassasah al-Risālah, 2000), Juz 24, Hal. 72.
} 
maka dari itu antara yang satu sama yang lain tidak boleh saling menasakh.

Maka, dengan alasan ini penulis berani menyebutkan bahwa penafsiran Zamakhshari yang berkaitan dengan pendapat Madhhab Muktazilahnya termasuk kekurangan dari tafsir al-Kashshāf.

\section{Pandangan Ulama terhadap Tafsīr al-Kashshāf}

Menurut Ibnu Khaldūn, tafsir al-Kashshāf merupakan salah satu tafsir yang paling baik dan paling mampu dalam mengungkapkan makna al-Qur'an dengan pendekatan bahasa dan balaghah serta i'rab-nya, kekurangan tafsir al-Kashshāf menurut beliau adalah sering membela faham muktazilahnya dalam menafsiri al-Qur' $\mathrm{an}^{25}$.

Sedangkan al-Dhhabì menilai bahwa tafsir al-Kashshāf (tanpa melihat pada sisi Muktazilahnya) merupakan kitab tafsir pertama yang mampu menyingkap kemukjizatan al-Qur'an, yang mampu mengungkap keindahan susunan dan balaghah al-Qur'an, meski ada beberapa ulama yang bisa mengungkap keindahan al-Qur'an, tapi berbeda dengan cara pengungkapan yang dilakukan oleh Zamakhshari, hal ini tidak lepas dari penguasaannya terhadap beberapa disiplin ilmu pengetahuan, lebih-lebih penguasaannya terhadap bahasa Arab, pengetahuannya akan shi'ir-shi'ir Arab, keahliannya dalam menguasai ilmu-ilmu balaghah, ilmu bayān, I'rāb, $a d a b$, dan kemampuannya meramu semua pengetahuannya ini dalam bentuk kitab yang bernama al-Kashshāf, sehingga membuat para ulama dan ahli tafsir menaruh perhatian terhadap kitab ini ${ }^{26}$.

Menurut Shaikh Haidar al-Harawi kitab al-Kashshāf merupakan kitab yang sangat istimewa, belum ada satu pun kitab yang sama sebelumnya, juga tidak ada orang yang bisa menyamainya, dari segi susunannya sangat menarik, sangat jelas sekali jika pengarangnya merupakan orang yang sangat menguasai kaidah tafsir, jika dibandingkan dengan tafsir-tafsir yang lain, al-Kashshäf tidak bertele-tele dalam ungkapannya, namun tidak ada kitab tafsir yang seindah kitab ini, sehingga tidak heran jika banyak orang menaruh

\footnotetext{
${ }^{25}$ Ibnu Khaldūn, Muqaddimah Ibnu Khaldūn, (Kairo: Maktabah at-Taufikiyah, t.th.), Hal. 489.

${ }^{26}$ Mohammad Husein al-Dhahabī, al- Tafsiri wa al-Mufassirūn, (Kairo: Dar alMa'arif, 2005), 366.
} 
perhatian pada kitab ini, dan menjadikan kitab ini terkenal ke semua penjuru, seperti halnya sinar matahari yang sangat terang di siang hari. Hanya saja, kitab ini memiliki kekurangan yang bisa menghilangkan keindahannya, dan menurunkan dejaratnya, diantaranya: setiap kali Zamakhshari menafsiri suatu ayat dalam alQur'an yang tidak sesuai dengan keinginannya, maka dia akan merubah makna lahir dariayat tersebut dengan cara yang sangat halus, dan ini termasuk kategori merubah firman Allah swt., di samping itu, Zamakhshari juga menuduh para wali Allah dengan tuduhan yang tidak layak, dan yang tidak kalah buruknya, Zamakhshari menyebut ahlu al-sunnah wa al-jamaah dengan sebutan yang sangat keji, kadang mereka disebut dengan orang-orang Jabariyah, kadang dinisbatkan pada kekufuran dan ateisme, dan ini merupakan cara orang-orang rendahan dan bukan cara-cara ulama yang baik. ${ }^{27}$

Abu Ḥayyān juga memiliki penilaian tersendiri mengenai kitab al-Kashshāf, beliau mengakui bahwa kitab al-Kashshāf memiliki beberapa kelebihan, kemudian beliau mengkritik alKashshāf dalam beberapa bait shair:

Tapi di dalamnya masih ada ruang bagi pengkritik

Kesalahan-kesalahan yang buruk datang mencekik

Sungguh sangat merugi bagi Shaikh

Yang nama baiknya mencakar langit timur dan barat

Jika Allah tidak memberinya rahmat

Orang-orang kafir akan jadi teman sejawat. ${ }^{28}$

Täjuddin al-Subkī juga memberikan komentarnya mengenai kitab Zamakhsharì dan al-Kashshāf-nya, beliau mengatakan dalam karyanya "Mu'ìd al-ni'am wa mubīd al-niqam", bahwa al-Kashshāf adalah termasuk kitab terbaik di bidangnya, pengarangnya pun memang ulama yang mumpuni di bidangnya, hanya saja ia termasuk ahli bid'ah yang bangga dengan kebid'ahan-nya, sering sekali merendahkan derajat kenabian, berperilaku kurang sopan terhadap ahlu al-sunnah wa al-jamā'ah, dan ini semua harus dikritisi. Shaikh Taqiyuddin al-Subkī (ayah dari Shaikh al-Täj al-Subki) pernah

\footnotetext{
${ }^{27}$ Haidar al-Harawi sebagaimana disebutkan dalam Kashf al-Zunūn karya Mullā Kātib Jalabī, (Dār al-Ṭibā'ah al-Mișriyah, 1274 H.), Juz 2, Hal. 176-177.

${ }^{28}$ Abu Hayyān, al-Baḥr al-Muhit, (al-Sa'adah, 1326), Juz 7, Hal. 85.
} 
membaca al-Kashāf, tapi kemudian berhenti ketika sampai surat alTakwir ayat 19:

$$
\text { إنه لقول رسول كريم }
$$

Beliau berpaling dan menulis di secarik kertas yang beliau beri nama "sabāb al-inkifäf 'an iqrā' al-Kashshäf', sebab berhenti membaca al-Kashāf. Dalam kertas tersebut, beliau menyatakan, "Menurutku, pendapat al-Zamakhshari dalam menafisiri lafaz" "عفا اله Sie", dan pendapatnya dalam surat al-Tahrim:

$$
\text { لم تحرم ما أحل اله للك }
$$

dan lain sebagainya itu termasuk perilaku yang tercela terhadap Rasulullah, oleh sebab itu, aku berhenti membacanya, karena merasa malu terhadap Rasulullah, meskipun di dalamnya termuat berbagi faedah-faedah dan goresan yang indah di dalam kitab tersebut. ${ }^{29}$

Dan masih banyak lagi beberapa penilaian ulama, yang penilaiannya tidak jauh berbeda dari pendapat Ibnu Khaldun, alZahabì, Abu Hayyān, dan Tãj al-Subkī, yaitu sama-sama menyoroti keistimewaan al-Kashshāf dari segi tafsir balaghi-nya dan mengkritik al-Kashshāf dari segi faham muktazilahnya.

Meski demikian, kitab ini mendapat sambutan baik bukan hanya dari golongan muktazilah saja, tapi dari golongan ahlu alsunnah wa al-jamaah juga mendapat apresiasi sangat baik, terbukti dengan adanya beberapa ulama yang mengedit atau men-takhrij hadis-hadis yang ada dalam kitab ini, seperti kitab, al-Kăfí al-Shāfí fí Takhrīj Ahādis al-Kashshāf(Uraian Lengkap Mengenai Takhrij Hadis Tafsir al-Kashshāf) oleh Ibnu Hajar al-'Asqalānī, al-Inshäf fī mä Taqaddamahū al-Kashshäf min al-I'tizāl (Menyingkap pandanganpandangan Mu'tazilah dalam Tafsir al-Kashshāf) oleh Imam Nashiruddin Ahmad bin Muhammad dan Ibnu Munìr al-Iskandarì.

Para ulama melakukan hal ini karena menganggap kitab tersebut merupakan kitab yang sangat berharga terutama jika ditinjau dari segi balaghah dan ilmu kebahasaannya, sehingga tidak heran ketika Imam Nashiruddin Ahmad bin Muhammad dan Ibnu Munir sampai mengarang kitab al-Inshäf, dengan tujuan menyaring faham muktazilah yang ada dalam kitab tersebut demi menyalamatkan para pembaca ahlu al-sunnah wa al-jamaah agar tidak terjebak dalam faham tersebut.

\footnotetext{
${ }^{29}$ Tāj al-Subkì sebagaimana dikutip oleh Mohammad Husein al-Dhahabī, dalam kitabnya al- Tafsirir wa al-Mufassirūn, (Kairo: Dar al-Ma'arif, 2005), 370.
} 
Membedah Al-KashshäF; Karya Muktazilah Yang Menjadi Rujukan Ahlussunah Wal Jamaah

\section{Metodologi dan Kecenderungan Tafsir al-Kashshāf}

Pada bagian ini, penulis membahas metodologi yang digunakan Zamakhshari dalam menulis tafsirnya sekaligus kecenderungannya.

\section{Segi Metode}

\section{Segi Sumbernya: bi al-Ra'yi}

Dilihat dari segi metode penafsirannya, secara sumber penafsiran, kitab tafsir al-Kashshäf ini termasuk kategori tafsir bi alra'yi. ${ }^{30}$ Hal ini bisa kita ketahui ketika Zamakhshari menafsirkan ayat 270 dari Surat al-Baqarah:

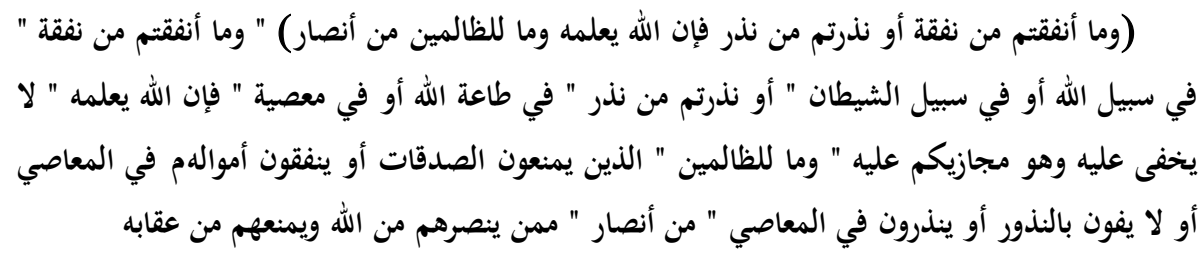

Zamakhshari menafsirkan dengan mengatakan: apa yang kalian infakkan (di jalan Allah atau di jalan Setan), atau sesuatu yang kalian nadhar-kan (dalam ketaatan atau kemaksiatan kepada Allah), maka sesungguhnya Allah mengetahuinya (tidak ada yang samar dari Allah, Dia akan member balasan bagi kalian atas apa yang kalian lakukan), orang-orang yang zālim (mereka yang tidak mau membayar sedekah, atau yang menafkahkan hartanya dalam kemaksiatan, atau mereka yang tidak menepati nadhar-nya atau mereka yang ber-nadhar dalam kemaksiatan) tidak akan menemukan penolong (orang yang bisa menolongnya dari kehendak Allah dan menghalangi siksaNya). ${ }^{31}$

Namun demikian, meski tafsir Zamakhshari tergolong tafsir $b i$ al-ra'yi dari segi sumbernya, bukan berarti dalam kitabnya tidak ada hadith Nabi atau qaūl sahabah, hanya saja keberadaannya tidak dijadikan tafsir langsung terhadap suatu ayat, tapi menjadi penguat dari pendapat Zamakshari sendiri dalam menafsiri ayat tersebut, seperti yang dia lakukan ketika menafsiri ayat:

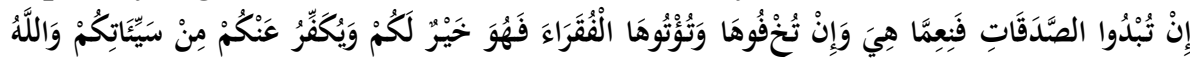

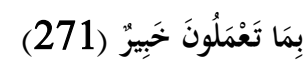

\footnotetext{
${ }^{30}$ Mahmud Basuni Faudah, Tafsir-tafsir al-Quran, terj. H.M. Mochtar Zaerni dan Abdul Qodir, (Bandung: Pustaka, 1987), Hal. 104.

${ }^{31}$ Zamakhshari, al-Kashshāf, (Kairo, Maktabah Misr, t.th.), Juz I, Hal. 281.
} 


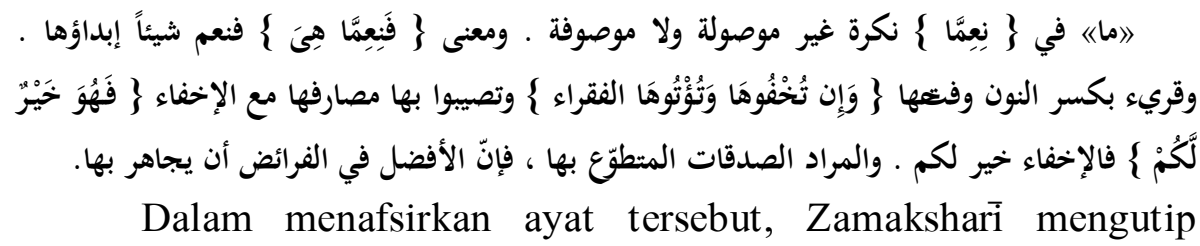
perkataan Ibnu Abbās ra.: sedekah sunnah dengan cara sembunyisembunyi lebih baik daripada cara terang-terangan tujuh puluh kali lipat, sedangkan sedekah wajib (zakat) dengan cara terang-terangan lebih baik daripada cara yang sembunyi-sembunyi dua puluh lima kali lipat. ${ }^{32}$ Zamakhshari menyebutkan riwayat ini bukan sebagai tafsir dari ayat yang sedang dibahas, tapi sebagai penguat pendapatnya yang disebutkan sebelumnya yang lebih dahulu dia mengatakan: sedekah dengan cara sembunyi-sembunyi lebih baik bagi kalian, dan maksudnya adalah sedekah sunnah, sedangkan dalam sedekah wajib lebih baik dilakukan dengan cara terang-terangan ${ }^{33}$.

\section{Segi Cara Penjelasan: Bayani}

Sementara dalam cara menjelaskan tafsirnya, Zamakhshari menggunakan metode bayani, seperti ${ }^{34}$ :

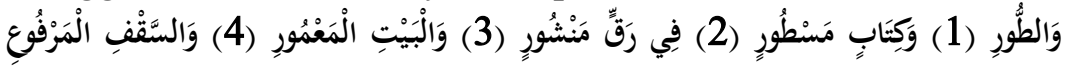

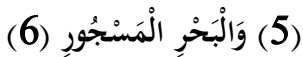

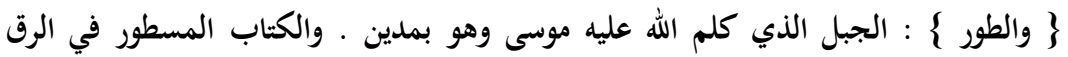

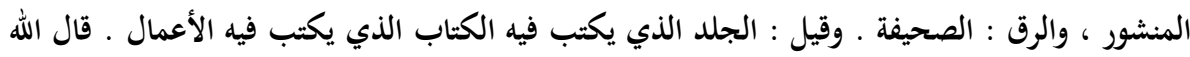

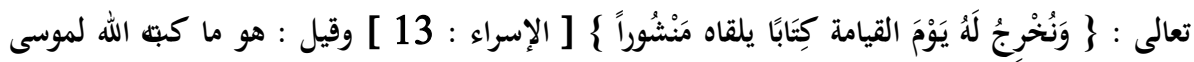

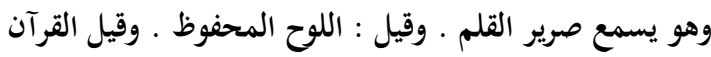

\section{Segi Keluasan Penjelasan: Tafșili}

Jika dilihat dari segi keluasan penjelasan, tafsir al-Kashshāf menggunakan metode tafsili, sebagaimana contoh berikut ${ }^{35}$ :

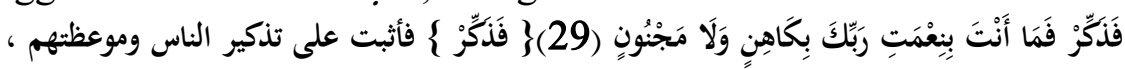

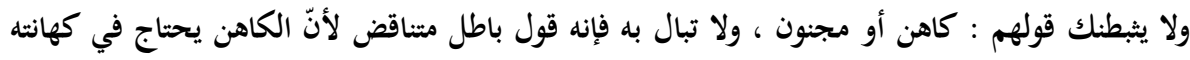

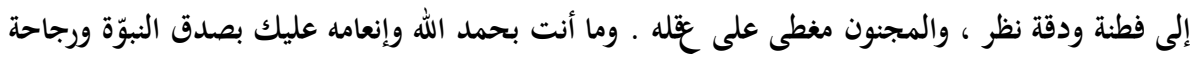

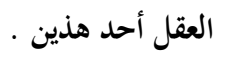

${ }^{32}$ Ibid. 281-282.

${ }^{33}$ Ibid. 282

${ }^{34}$ Ibid. Juz 4, hlm. 289.

${ }^{35}$ Ibid. Juz 4, hlm. 293. 
Membedah Al-KashshāF; Karya Muktazilah

\section{Segi Urut dan Tertib Ayat: Tah̆hili}

Sedangkan dari segi susunan dan tertib ayat yang ditafsirkan termasuk kategori tafsir tahlili, yaitu suatu metode tafsir yang mengkaji ayat-ayat al-Qur'an dengan memaparkan segala makna dan aspek yang terkandung di dalamnya sesuai dengan urutan bacaan (ayat dan surat) dalam muṣhaf Uthmani, karena al-Zamakhsyari melakukan penafsiran secara lengkap terhadap seluruh ayat yang terdapat dalam al-Qur'an dari awal hingga akhir, mulai dari ayat pertama Surat al-Fātihah sampai ayat terakhir Surat al-Nās.

Hal ini bisa kita buktikan dengan contoh berikut: ${ }^{36}$

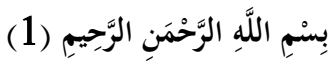

قرّاء المدينة والبصرة والشأم وفقهاؤها على أنّ التسمية ليست بآية من الفاتحة ولا من غيرها من السور ،

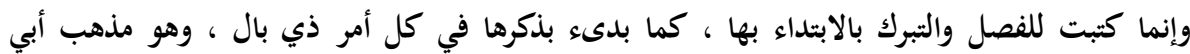
حنيفة - رحمه الله - ومن تابعه ، ولذلك لا يجهر بها عندهم في الصلاة ـ وقرّاء مكة والكوفة وفقهاؤهما

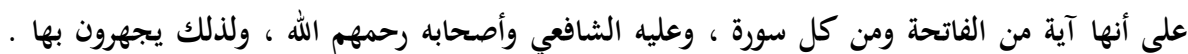

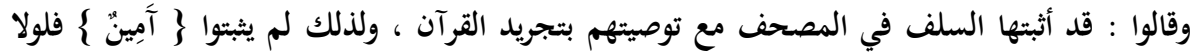

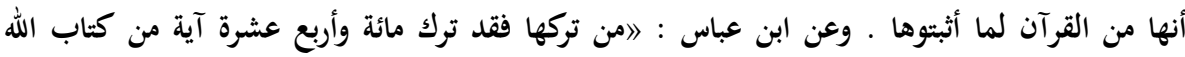

Zamakhshari memulai tafsirnya dengan menafsiri ayat basmalah, yaitu ayat pertama dari Surat al-Fätihah dan Zamakhshari melanjutkan penafsirannya pada ayat kedua, ketiga dan seterusnya sampai pada ayat terakhir dari al-Qur'an, yaitu ayat ke 6 dari Surat al-Nas ${ }^{37}$ :

\} مِنَ الجنة والناس \{ بيان للذي يوسوس ، على أن الشيطان ضربان : جنى وإنسي ، كما قال \} شياطين

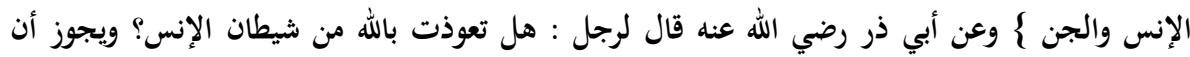

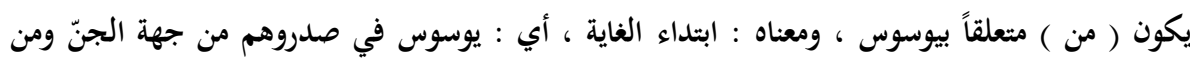

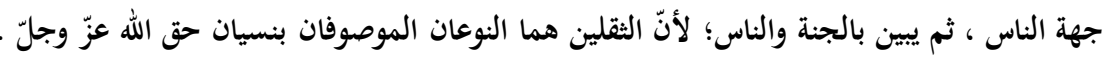

Dengan demikian bisa dipastikan bahwa tafsir al-Kashshäf menggungkan metode tahlili jika dilihat dari segi susunan dan tertib ayat yang ditafsirkan.

\section{Segi Kecenderungan atau Aliran}

${ }^{36}$ Ibid. Juz 1, Hal. 11-15.

${ }^{37}$ Ibid. Juz 4, hlm. 657. 
Sementara, dari segi kecenderungannya, tafsir al-Kashshāf menganut aliran adabī dan i'tiqādi, hal ini tidak bisa lepas dari latar belakang Zamakhshari sendiri yang memang mumpuni dalam bidang kebahasaan dan merupakan penganut faham Muktazilah, kedua kecenderungan ini nampak sekali dalam tafsir al-Kashshäf, misalnya:

a. Adabi

Tafsir al-Kashshāf sangat kental sekali dalam kecenderungan adabi-nya, diantara contoh yang menguatkan hal ini adalah ketika Zamakhshari menafsirkan ayat:

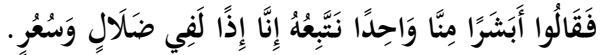

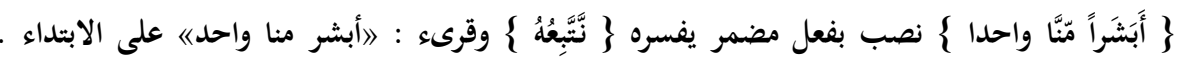

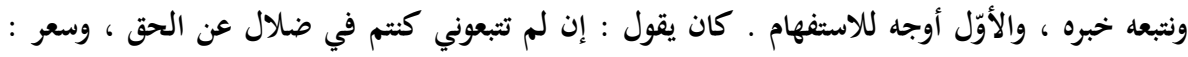

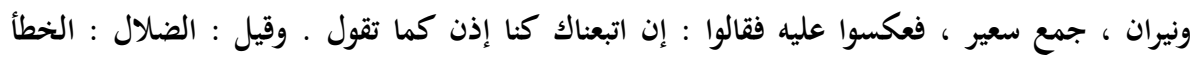

$$
\begin{aligned}
& \text { والبعد عن الصواب ـ والسعر : الجنون ـ يقال : ناقة مسعورة . قال : }
\end{aligned}
$$

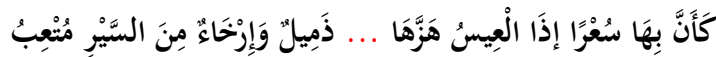

Jika kita perhatikan, ketika Zamakhshari menafsirkan ayat di atas, Zamakhshari terlebih dahulu membahas suatu ayat dari segi bahasanya dengan mengatakan lafadh abasharan minnā wähidan, dibaca nasab dengan fi'l (kata kerja) yang di-mudmar-kan (disembunyikan) dengan penafsiran (nattabi'uhū), lafadh abasharan juga dibaca abasharun minnā wāhidun sebagai mubtada', sedangkan nattabi'uhu sebagai khabar-nya, dan cara baca yang pertama lebih cocok sebagai istifhām (kata tanya). Dia mengatakan: jika kalian tidak mengikuti ku, maka kalian akan tersesat dari jalan yang benar. ${ }^{38}$

\section{b. I'tiqāadi}

Sedangkan contoh yang menunjukkan bahwa Zamakhshari memiliki kecenderungan I'tiqādì bisa kita temukan dalam penafsiran beliau terhadap beberapa ayat al-Qur'an yang membahas masalah akidah, terutama yang berkaitan dengan fahamnya sendiri, yaitu faham Muktazilah. Sebagai contoh dari kecenderungan i'tiqädi-nya Zamakhshari dalam tafsir al-Kashshāf adalah ketika beliau menafsirkan ayat 7 dari Surat al-Baqarah: ${ }^{39}$

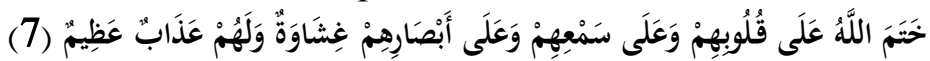

38 Ibid. Juz 4, Hal. 312.

${ }^{39}$ Ibid. Juz 1, hlm. 49-52. 
الختم والكتم أخوان؛ لأن في الاستيثاق من الشيء بضرب الخاتم عليه كتماً له وتغطية لئلا يتوصل إليه ولا يطلع عليه

والغشاوة : الغطاء فعالة من غشاه إذا غطاه ، وهذا البناء لما يشتمل على الشيء كالعصابة والعمامة . فإِن

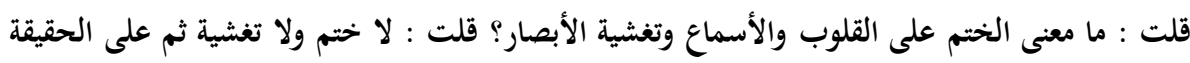

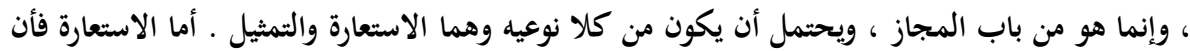

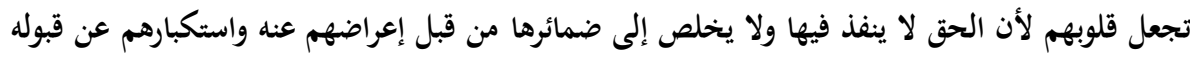

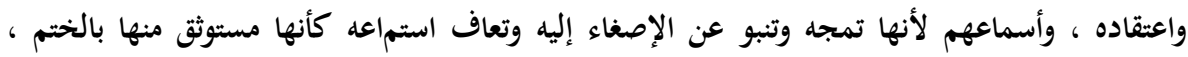

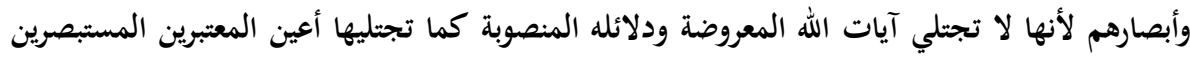

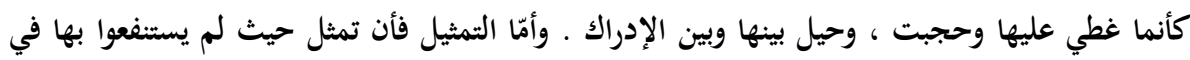
الأغراض الدينية التي كلفوها وخلقوا من أجلها بأشياء ضرب حجاب بينا بينها وبين الاستنفاع بها بالختم والتغطية ـ وقد جعل بعض المازنيين الحبسة في اللسان والعيّ ختماً عليه فقال التحال

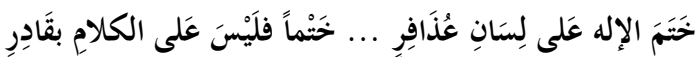

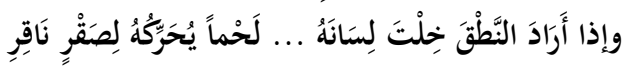

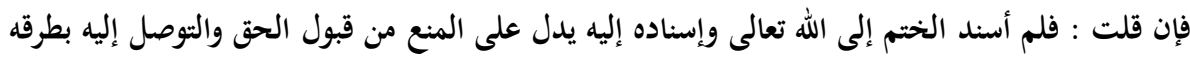

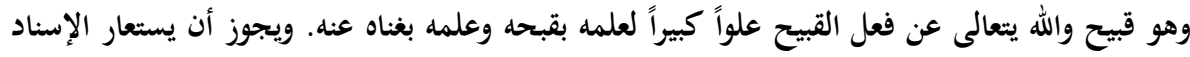

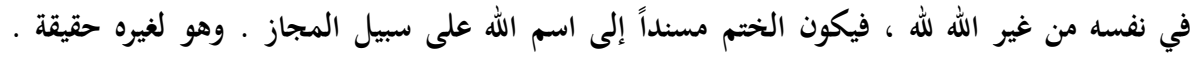

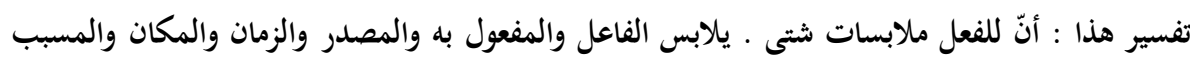

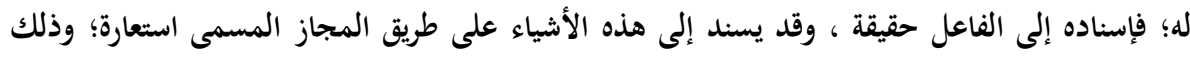

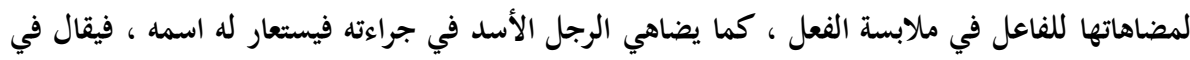

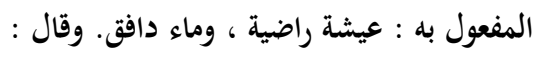

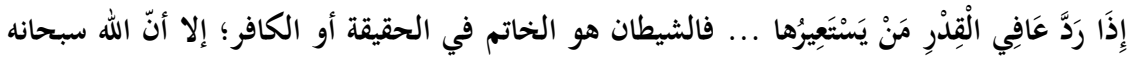

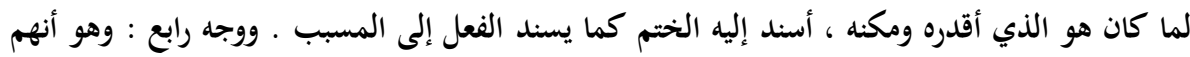

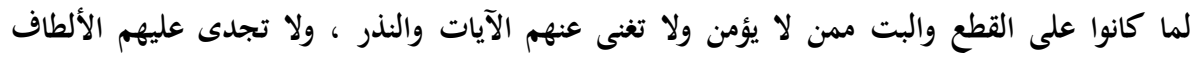

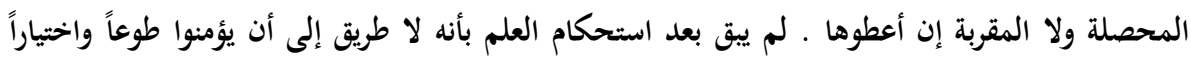
طريق إلى إيمانهم إلا القسر والإلجاء ، وإذا لم تبق طريق إلا أن يقسرهم الله ويلجئهم ثم لم يقسرهم ولم الم الماله

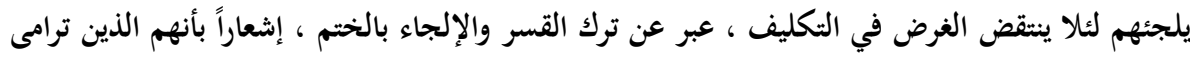

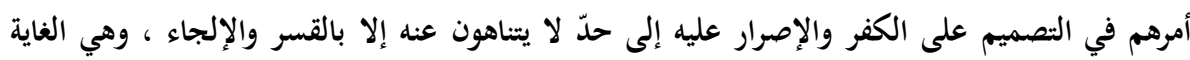

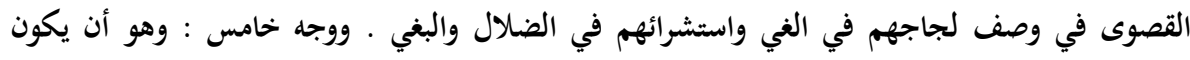

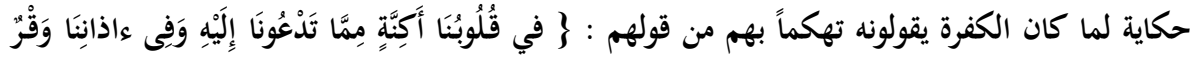




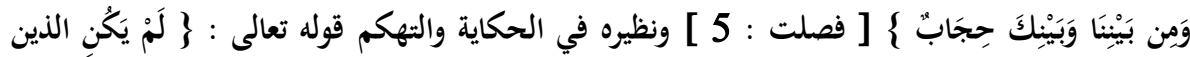

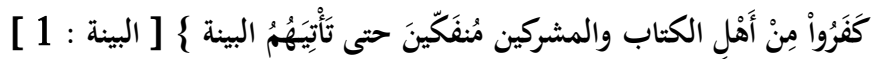

Kata khatama, menurut Zamakhshari sama dengan kata katama dan kata ghishäwah sepadan dengan pengertian githä'. Zamakhshari kemudian menafsirkan ayat di atas dengan penafsiran bahwa Allah tidak menutup dan mengunci mati hati, pendengaran, dan penglihatan mereka secara hakiki, firman Allah di atas bermakna majäzi ${ }^{4 \theta}$ yang jika ditilik dari segi ilmu baläghah, mengandung dua kemungkinan, yaitu: bisa dalam bentuk isti'ärah, dan bisa juga dalam bentuk tamthïl.

Ayat di atas bisa disebut berfungsi dalam bentuk isti'ärah, karena sesungguhnya hati, pendengaran, dan penglihatan merekalah yang tertutup. Hati mereka dianggap tertutup karena kebenaran yang datang dari Allah tidak akan bisa menembus apalagi sampai ke dalam hati nurani mereka. Hal ini tidak lain karena keengganan mereka untuk menerima kebenaran dan untuk meyakininya.

Ungkapan dalam ayat itu bisa juga disebut sebagai tamthil, karena mereka tidak mengambil manfaat sedikitpun dari petunjuk yang diberikan kepada mereka, dan mereka menggantikannya dengan sesuatu yang lain yang dapat diibaratkan sebagai penutup (hijab) yang dapat mengunci mati, sehingga kebenaran yang datang dari Allah tidak dapat mereka terima. Oleh sebab itu, mereka tidak bisa mengambil manfaat dari kebenaran tersebut.

Lantas, jika ada orang yang bertanya, mengapa kata khatama disandarkan kepada Allah? Zamakhshari menjawab bahwa penyandaran hal itu kepada Allah merupakan kināyah terhadap sikap mereka yang sangat berlebihan dalam menolak petunjuk Allah, yang sudah tertanam di dalam hati, pendengaran, dan penglihatan mereka, yang menurut Zamakhshari, semuanya adalah makhluk Allah swt. penyandaran ini dimaksudkan untuk menyebutkan sesuatu yang lāzim, tetapi yang dimaksudkan sebenarnya adalah yang malzūm, dan

\footnotetext{
${ }^{40}$ Teks al-Qur'an dan Hadith tidak boleh dialihkan dari makna hakiki ke makna majazi kecuali jika makna hakiki tersebut bertentangan dengan prinsip-prinsip shari' ah. Zamakhshari menyatakan, jika ayat di atas diberi makna hakiki, maka akan memberi kesan bahwa Allah berbuat zalim terhadap hamba-Nya, padahal Allah berfirman:

وَمَا رَبُكَكَ بظلام لَلْعِبيدِ: dan tidaklah Tuhanmu berbuat ẓalim terhadap hamba-Nya.(Fussilat: 46).
} 
itulah sebenarnya yang menjadi maksud utama dalam ungkapan ayat di atas, seperti ungkapan:

فلان مجبول على كذا ومفطور عليه : Si Fulan (Anu) diciptakan dengan watak demikian dan memang fitrahnya seperti itu. Dengan kata lain orang tersebut sangat kuat memiliki sifat yang demikian. ${ }^{41}$

Zamakhshari menafsirkan ayat di atas dengan penafsiran seperti ini, karena menurutnya yang juga merupakan pendapat Muktazilah, perbuatan tersebut dianggap perbuatan buruk yang tidak boleh disandarkan kepada Allah swt.

Penafsiran seperti ini terkesan dipaksakan oleh Zamakhshari, karena jika ayat ini tidak dialihkan pada makna majazi, maka akan menjadi bantahan terhadap pendapat Muktazilah yang berpendapat bahwa Allah tidak mungkin berbuat buruk terhadap hamba-Nya.

Penulis melihat ketidakkonsistenan Zamakhshari dalam mempertahankan pendapatnya, hal ini terlihat jelas ketika kita bandingkan penafsiran Zamakhshari terhadap ayat 7 dari Surat alBaqarah dengan ayat yang berbunyi:

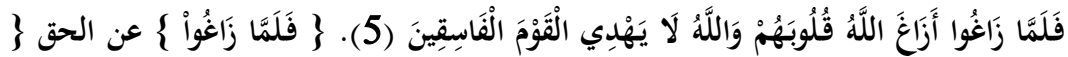

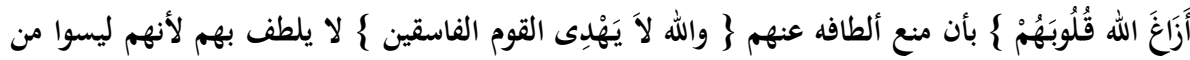

أهل اللطف

"Maka tatkala mereka berpaling dari kebenaran, Allah memalingkan hati mereka"42. Zamakhshari menafsirkan kata azāghallāh qulübahum dengan penafsiran, Allah mencegah kasih sayang-Nya kepada mereka. Semestinya, jika Zamakhshari konsisten pada pendapatnya bahwa Allah tidak mungkin berbuat buruk kepada hamba-Nya, beliau tidak akan menafsirkan demikian, dan akan mencari cara untuk menjustifikasi pendirinya sebagaimana yang beliau lakukan ketika menafsirkan Surat al-Baqarah ayat 7.

\section{Epilog}

Terlepas dari berbagai pandangan ulama mengenai kitab alKashshāf, penulis merekomendasikan setiap muslim, apapun faham yang dianutnya untuk membaca kitab ini, karena kitab ini memiliki keistimewaan yang sangat penting bagi kita semua, yaitu unsur kebahasaan yang dibahas sangat mendalam dalam kitab ini, ketika

${ }^{41}$ Zamakhshari, al-Kashshāf, (Kairo, Maktabah Misr, t.th.), Juz 1, hlm. 50.

${ }^{42}$ Departemen Agama, al-Qur'an dan Terjemahnya, (Surabaya, UD. Mekar, 2000), 926. 
menafsiri suatu ayat, Zamakhshari tidak hanya berdasarkan ayat-ayat al-Qur' an yang terdapat pada ayat maupun surat yang lain, tapi juga berdasarkan pada Hadith Nabi dan syair-syair Arab yang merupakan sumber terpenting dalam tafsir kebahasaan al-Qur' an, meskipun harus kita akui adanya ayat al-Qur'an maupun Hadith tersebut bukan semata-mata untuk menafsirkan al-Qur'an secara langsung, tapi sebagai penguat dari pendapat Zamakhshari sendiri.

Setelah membaca tafsir Zamakhshari yang lebih menonjolkan sisi kebahasaan al-Qur'an kita akan lebih mengagumi kemukjizatan al-Qur'an dari segi bahasa dan balaghahnya. Namun, yang perlu diperhatikan adalah ketika membaca tafsir beliau yang berkenaan dengan aqidah, karena beliau masih terikat dengan faham yang dianutnya dalam menafsiri ayat-ayat tersebut. Maka, kita perlu mengapresiasi beberapa ulama yang telah memurnikan kitab alKashshäf dari faham Muktazilah.

Sementara metodologi yang digunakan oleh Zamakhshari dalam tafsir al-Kashshäf jika ditilik dari sumbernya termasuk kategori tafsir bi al-ra'yi, berdasarkan cara penjelasannya termasuk kategori bayāni, berdasarkan sasaran dan tertib ayatnya termasuk kategori tafsir tahlili, berdasarkan keluasan penjelasannya termasuk kategori tafsir tafsili, dan dilihat dari segi kecenderungannya termasuk tafsir adabī dan i’tiqādi yang Muktazili.

\section{Daftar Pustaka}

Agama, Departemen, al-Qur'an dan Terjemahnya, Surabaya, UD. Mekar, $2000 \mathrm{M}$.

Al-Andalūsì, Abu Hayyān, al-Bahr al-Muhit, t.t,al-Sa'adah, 1326 H.

Al-Bukhārī, Muhammad bin Isma'ìl, Shahīh al-Bukhāri, Bairūt, Dār Ibnu Kathï, 1987 M.

Al-Dhahabī, Muhammad Husaīn, al-Tafsīr wa al-Mufassirūn, Kairo, Dār al-Hadith, $2005 \mathrm{M}$.

Faudah, Mahmūd Basūni, Tafsir-tafsir al-Quran, terj. H.M. Mochtar Zaerni dan Abdul Qādir, Bandung: Pustaka, 1987 M.

Ibnu Kathïr, Abū al-Fidā' Isma'ìl bin Umar, Tafsir al-Qur'ān al'Adhìm, t.t. Dār Tayyibah, 1999 M.

Ibnu Khaldūn, Abdurrahmān bin Muhammad, Muqaddimah Ibnu Khaldūn, Kairo: Maktabah at-Taufikiyah, t.th.

Jalabī, Mullāa Kātib, Kashf al-Zunūn, Kairo, Dār al-Ṭibā'ah alMișriyah, $1274 \mathrm{H}$. 
Al-Qatțān, Mannā' Khalil, Studi Ilmu-ilmu al-Qur'an, terj. Mudzakir AS. Jakarta: Litera Antarnusa, $2001 \mathrm{M}$.

Al-Tabarì, Ibnu Jarī̄, Jāmi' al-Bayān fì Ta'wìl al-Qur'ān, Bairūt, Muassasah al-Risālah, $2000 \mathrm{M}$.

Al-Zamakhsharī, Mahmūd bin Umar, al-Kashshāf 'an haqāiq al-tanzīl wa 'uyūn al-aqāwìl fì wujūh al-Ta'wìl, Kairo, Maktabah Misr, t.th. 